\title{
A social costs and benefits analysis of peat soil-subsidence towards 2100 in 4 scenarios
}

\author{
Tim A. H. M. Pelsma ${ }^{1}$, Anne Marieke Motelica-Wagenaar ${ }^{1}$, and Simon Troost ${ }^{2}$ \\ ${ }^{1}$ Waternet, P.O. Box 94370, 1090 GJ, Amsterdam, the Netherlands \\ 2't Salland, Luttenberg, the Netherlands
}

Correspondence: Tim A. H. M. Pelsma (tim.pelsma@waternet.nl)

Published: 22 April 2020

\begin{abstract}
Waternet is the executive agency of the regional water authority Amstel, Gooi and Vecht. Water authority Amstel, Gooi and Vecht manages the water levels (ditches) for 19400 ha of peat meadows around the Netherlands capital Amsterdam. At present the ditches levels at about $40-60 \mathrm{~cm}$ beneath the peat meadow surface, resulting in a groundwater level between from 30 until $80 \mathrm{~cm}$ below peat surface and a subsidence of about $9 \mathrm{~mm}$ each year. A study was carried out on peat soil subsidence in the Amstel, Gooi and Vecht water authority water management area towards 2100: for short term effects (until 2027), midterm effects (until 2050) and longer term effects (until 2100). This study explores 4 scenarios: (1) present policy (maintain ditch waterlevel at maximum $60 \mathrm{~cm}$ below surface); (2) active rewetting, groundwater level at surface; (3) passive rewetting, subsidence is not compensated by lowering of water levels; (4) subsurface irrigation by submerged drains (infiltration in summer, drainage in winter). The scenarios are compared on farming, houses, public infrastructure, greenhouse gases and water management.

At present, the total net benefit for farmers are EUR 7 million per year for the whole area, while the costs for the water authority are EUR 37 million per year for managing ditches, dikes and pumps. Costs for greenhouse gases are EUR 18 million (at a price of EUR 40 per ton $\mathrm{CO}_{2}$-eq). Active rewetting would reduce soil subsidence maximally from 2 to $0.5 \mathrm{~m}$ towards 2100 but reduces the benefits for farming, whilst the costs for water management stay alike. The costs for greenhouse gases however drops with EUR 3 million per year immediately because $\mathrm{CO}_{2}$-eq emissions drops. Best (financial) results (with respect to all stakeholders) on the long term are booked by passive rewetting with lower costs for water management, houses, public works and greenhouse gases. This scenario will eventually take away the farming possibilities, but not before 2050 and could be too slow to contribute strongly to Paris agreement goals. Best result with respect to climate for short and long term is active rewetting, which will drop the greenhouse gas emissions strongly (equivalent of EUR 2.3 million per year), reduce soil subsidence, but makes farming harder (drop from 7.1 up to EUR 2.5 million per year benefit) and brings no direct reduction of costs for the water authority. Best result on short term for farmers is submerged infiltration drains. However, the effect of this scenario on GHG emission is limited in this study.
\end{abstract}

\section{Introduction}

Water authority Amstel, Gooi and Vecht (AGV, operated by Waternet; see AGV, 2019 for policy on soil subsidence) is responsible for water levels and water quality in the peatmeadow area around the capital Amsterdam (see Fig. 1 for distribution of the peat soils). The drainage ditches in the peat levels in the area between 30 and $60 \mathrm{~cm}$ (by policy of the authority) below the peat surface, thus draining the toplayer of the peatsoil. This management causes the soil subsidence by $9 \mathrm{~mm}$ each year (van den Born et al., 2016) as a side effect of making the soils suitable for agricultural use. The latter works well, the soils are very productive grasslands, cattle (milk) farming on peat soil is profitable. Before the year 1200, the peatbogs elevated above the rivers and lakes, but after eight hundreds of years of soil subsidence, this has turned around. The peatsoils dropped several me- 
ters and are now low lands: polders. Polders with typically an elevation around or even well below $(-3 \mathrm{~m})$ sea-level. In the peat-meadow area of AGV the yearly costs for one hectare of water maintenance (dikes and assets) are around EUR 1539 (this study), whilst the (net) profits of a farmer are lower (around 200-EUR 1000 per hectare per year, van den Born et al., 2016). The landuse (grassland farming with drainage ditches) is not without consequences. Besides subsidence and direct cost like pumping stations and dikes, or foundations of houses, the emitted (large) amounts of $\mathrm{CO}_{2}$, $\mathrm{CH}_{4}$ and $\mathrm{N}_{2} \mathrm{O}$ from the peat has be taken in to account too. Subsidence and oxidation of the peat also causes the cover layer (on sand or clay) of polders to disappear, making them more vulnerable to seepage from higher water levels around, leakage in fact. This seepage water could be salt or brackish, thus causing troubles in nature, agriculture and the preparation for drinking water. The higher parts in the area (often peat wetlands or peaty nature reserves) are drained by the surrounding lower polders. A very important aspect of peat drainage (and peat soil subsidence) is the release of nutrients from the peat itself by oxygen and other (oxidizing) substances (like $\mathrm{SO}_{4}$ or $\mathrm{NO}_{3}$ ) entering the peat. It appears (van Beek et al., 2007) that the decomposition of peat is an important source for the loads of nitrogen and phosphorus to the waterbodies in peat area's and can be seen as a result of land-use, even without taking the fertilizer into account.

By performing a social costs and benefit analysis, the water authority gains more insight in several aspects of the water management in peat areas and takes more responsibility for side effects of drainage of peat. The aim of our authority (with respect to soil subsidence and water related land use) is to contribute to a sustainable development of the peat areas, including its users, over time.

The present policy in peat-meadow "polders" is to "follow" the subsidence with lowering of the ditch waterlevels from time to time, with some exceptions. Basically we expect this present policy to be suitable for the future. The cost/benefit analyses was carried out to reject or prove this hypothesis by comparing present policy with 3 alternatives towards 2027, 2050 and the year 2100 .

We further expect that a future cost/benefit exploration will give more insight for policy makers to decide on strategy against (peat)soil subsidence, which typically is a long term process. We think that by calculating the more extreme scenarios of measures taken everywhere (active rewetting, submerged infiltration pipes) against the present policy will make a clear difference on the longer term of 2050 or even the year 2100. Because changes in land use will be required on quite a large scale to really slow down the soil subsidence, it is required to have a few looks from different angles of view toward the future, since changes in land use takes many years or even decades to be implemented.

Which approach in water management of the peat area of AGV is most sustainable for farmers and water authority but also for society (including all economical aspects) as a whole? In each approach: what will be the soil subsidence, farmer profit, emissions of greenhouse gases, costs for houses, costs for infrastructure and costs for water authority towards 2027, 2050 and 2100?

\section{Material and Methods}

For the water management area of the Water Authority AGV, an analysis is performed to determine the social costs and benefits due to soil subsidence for four scenarios (see Table 1). Three of these scenarios represent comparable policies to the policies analyzed in the study of van den Born et al. (2016). Active rewetting is added as an extra scenario as this is expected to have the highest impact in lowering GHG emissions and soil subsidence:

All scenarios are analysed in year 2016-2017 (as "present")

- 2027 - Shows effects on the short term (within 1 term of policy)

- 2050 - Shows effects on the mid-term (fitting in 1 human generation)

- 2100 - Shows effects on the long term (fitting in 2 human generations and fitting the terms used in climate adaptation)

The analyses were carried out with the model RE:PEAT (Developed at water authority Stichtse Rijnlanden, Houten, Netherlands). RE:PEAT (Waterschap Stichtse Rijnlanden, 2017) is available as a spreadsheet calculation core. Soil subsidence is calculated for those land-areas with a peat soil or a peat soil with a clay cover, using the land subsidence model Phoenix in RE:PEAT, as follows:

Soil subsidence rate $(\mathrm{m} \mathrm{yr})=0.02354$

$\cdot$ [mean lowest groundwaterlevel $(\mathrm{m})]+0.01834$

$\cdot[$ thickness clay cover $(\mathrm{m})]+0.00668$

In the study, the AGV water management area is subdivided into urban and rural area. The analysis is performed for each polder subunit. Effects of soil subsidence on economy of urban and rural areas are based on PBL study (van den Born et al., 2016). The analysed features in the analysis are shown in Table 2. Note: The individual results of the polder subunits are not presented in this paper, but are available. We only present the results of the complete AGV peat area.

Taxes (for households, farmers as a cost or for authorities as a profit) were not modelled.

An analyses of Sensitivity to assumptions was carried out for milk price, food price, paludiculture (only added in sensitivity analysis), interest rate, climate scenario.

Other important settings and basic assumptions for the model were: 
Table 1. The applicable scenarios in the analysis.

\begin{tabular}{|c|c|c|c|c|}
\hline $\begin{array}{l}\text { Scenario } \\
\text { number }\end{array}$ & $0(\mathrm{PP})$ & $1(\mathrm{AR})$ & $2(\mathrm{PR})$ & $3(\mathrm{SD})$ \\
\hline Title & Present policy & Active rewetting & Passive rewetting & $\begin{array}{l}\text { Submerged irrigation } \\
\text { drainage }\end{array}$ \\
\hline $\begin{array}{l}\text { Purpose of } \\
\text { scenario }\end{array}$ & $\begin{array}{l}\text { To show the } \\
\text { consequences of the } \\
\text { present policy of } \\
\text { continous ditch level } \\
\text { lowering }\end{array}$ & $\begin{array}{l}\text { To minimize the soil- } \\
\text { subsidence by strong } \\
\text { ditch level rise }\end{array}$ & $\begin{array}{l}\text { To minimize or stop the } \\
\text { soil-subsidence on the } \\
\text { long term }\end{array}$ & $\begin{array}{l}\text { To slow down the soil- } \\
\text { subsidence by applying } \\
\text { submerged irrigation } \\
\text { drains. }\end{array}$ \\
\hline $\begin{array}{l}\text { Waterlevel } \\
(2016)\end{array}$ & $\begin{array}{l}\text { Present water levels } \\
\text { (between } 25 \text { and } 60 \mathrm{~cm} \\
\text { below landsurface) }\end{array}$ & $\begin{array}{l}\text { Waterlevel } 10 \mathrm{~cm} \text { below } \\
\text { land surface }\end{array}$ & Present water levels & Present water levels \\
\hline $\begin{array}{l}\text { Waterlevel } \\
\text { alteration } \\
\text { after } 2016\end{array}$ & $\begin{array}{l}\text { Adjust the ditch level } \\
\text { with the average } \\
\text { subsidence of the polder } \\
\text { section }\end{array}$ & $\begin{array}{l}\text { Adjust the ditch level } \\
\text { with the average } \\
\text { subsidence of the polder } \\
\text { section }\end{array}$ & $\begin{array}{l}\text { None, unless waterlevel } \\
\text { within } 10 \mathrm{~cm} \text { of land sur- } \\
\text { face (in that case as AR) }\end{array}$ & $\begin{array}{l}\text { Adjust the ditch level } \\
\text { with the average } \\
\text { subsidence of the polder } \\
\text { section }\end{array}$ \\
\hline $\begin{array}{l}\text { Exceptions in } \\
\text { waterlevels }\end{array}$ & $\begin{array}{l}\text { Fixed levels in urban } \\
\text { areas }\end{array}$ & $\begin{array}{l}\text { No alteration in level in } \\
\text { urban areas in compari- } \\
\text { son with present }\end{array}$ & $\begin{array}{l}\text { Fixed levels in urban } \\
\text { areas }\end{array}$ & $\begin{array}{l}\text { Fixed levels in urban } \\
\text { areas, but also in area's } \\
\text { with seepage }\end{array}$ \\
\hline
\end{tabular}

Table 2. Analyzed features.

\begin{tabular}{ll}
\hline Stakeholder/theme & Kind of effect \\
\hline Water authority & $\begin{array}{l}\text { Costs sluices/pump. stations \& watermanagement } \\
\text { Costs sludge removal } \\
\text { Costs dikes } \\
\text { Shortage of waterstorage }\end{array}$ \\
\hline Public works & Roads, sewage system and cables \\
\hline Households & Costs foundation \\
& Costs groundwater damage \\
\hline Nature \& Landscape & Landscape \\
& Meadow birds \\
Water quality, nutrients in surface water
\end{tabular}

\subsection{Soil type, groundwater table and presence of clay on peat}

The exact thickness of the peat soil is unknown, it is assumed in the calculations that for all peat soils, soil subsidence continues until 2100 . For the soil type and the presence of a clay layer the BOFEK 2012 soil map of The Netherlands was used (Wosten et al., 2013). Very thin clay layers ( $<7.5 \mathrm{~cm}$ of clay) were ignored, because the field experience of employees of the water authority pointed out that in these areas there was no clay at all (but strongly decomposed peat). See Fig. 2 for the used clay thickness.

\subsection{Greenhouse gases}

Effects of soil subsidence on greenhouse gas (GHG) emissions are based on the relation between mean groundwater level and GHG emission (Jurasinski et al., 2016). The GHG emission is corrected for clay cover thickness. We assumed EUR 40 per ton carbon dioxide as a price in the model, making the emissions from peat, a cost. Jurasinski's et al. (2016) tool is performed on mean groundwater levels and calculates for $\mathrm{CO}_{2}, \mathrm{CH}_{4}$ and $\mathrm{N}_{2} \mathrm{O}$. Note that soil subsidence in our approach is based on the mean lowest groundwater levels, while 


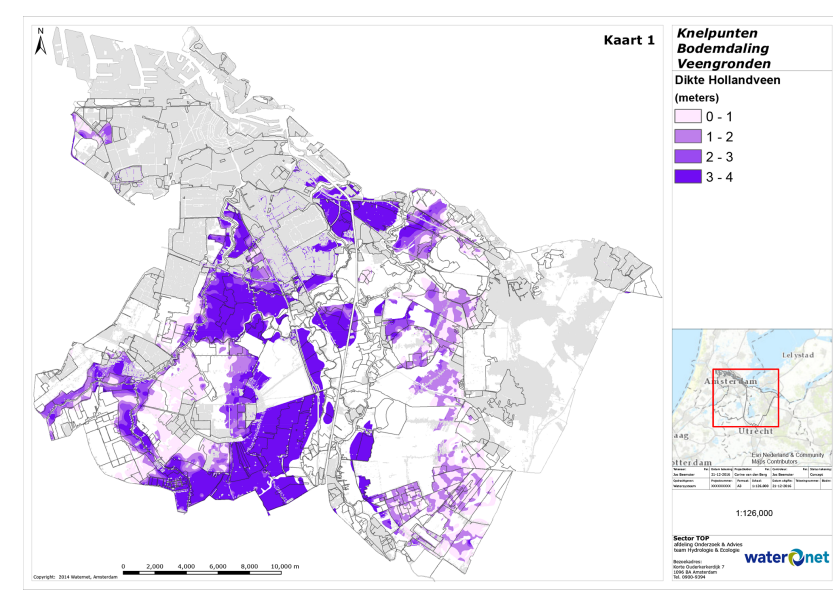

Figure 1. Water authority area Amstel Gooi and Vecht (with Amsterdam middle-north/west of map) and the presence of peat soils. Gray/white is urban area or no peat soils. Dikte Hollandveen = Thickness peatlayer. Map and map-topography is a strongly modified version of dutch GEOTOP map, published by TNO- Geologische Dienst Nederland, 2012.

the emissions of GHG is based upon mean groundwater levels.

\subsection{Agriculture chain}

In most scenarios the meadows become wetter. As a result the grass yield is modelled less and therefore also more costs for cattle-food. In other words: wetter peat means more costs for the farmer. Other figures for agriculture costs and profits (like milk price or costs for new sheds) are not included in this paper, but of course play an important role in the modelled calculations (see also the sensitivity analysis in Results and Discussion).

The effects on the market chain (milk products, food suppliers) is not part of the model. We follow in this the line of van den Born (2016), where is stated that effects in one part of the chain should not be transferred to the next part in a healthy market. The food industry is considered as a healthy market. We also assume in our model that farmers will continue the present use of the farm and the land use will remain.

\subsection{Foundations of buildings}

The lowest groundwater levels determine the effect on the wooden foundation piles, hence the period that wooden parts are exposed to oxygen and starts weakening. The longer the period of low groundwater levels (related to subsidence) the higher the (long term) costs. Only one repair is taken into account, existing damage is not taken into the model. Older houses brings higher costs. High ground water levels can also bring costs. The model assumes costs when the highest groundwater level is more than $70 \mathrm{~cm}$ below surface. Costs for water damage because of more rain, more upward seep-

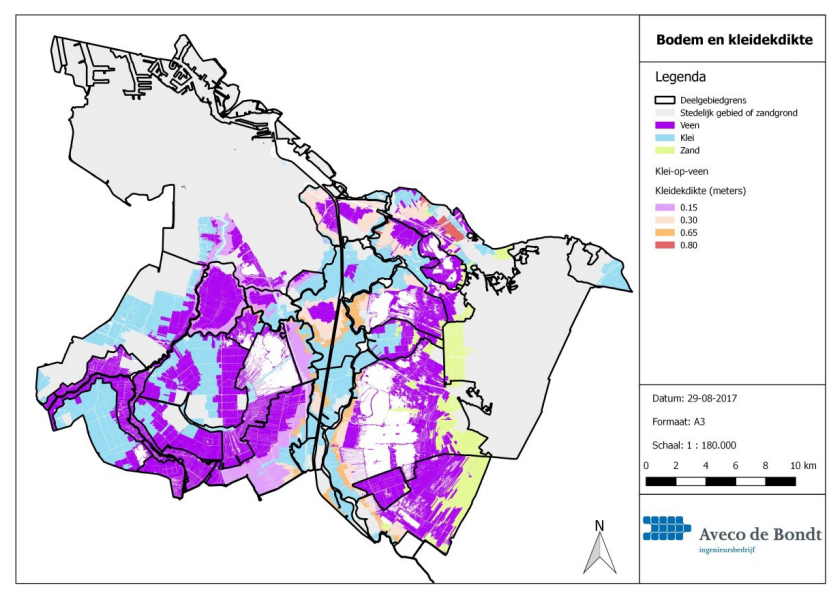

Figure 2. Soil types and thickness of clay layer in the AGV area. Veen $=$ Peat; Klei $=$ clay; Zand $=$ sand; kleidekdikte $=$ thickness of claylayer. Grey = Urban area or sand soil. Map is a modified version of BOFEK2012, de nieuwe bodemfysische schematisatie van Nederland. Published by Alterra 2013.

age, already fixed water levels and flotation of peat are not modelled.

\subsection{Public works (roads, pipes, cables)}

Subsidence makes that these assets must be repaired more often, the stronger the subsidence, the higher the costs. Differences in costs were made for sewage systems, dikes, roads and pipes. Peat subsidence has an oxidation and a compression factor in it. Only the oxidation factor is modelled.

\subsection{Water authority}

Assets (like pumps, pipes and weirs) were written off in 25 years. Polders are subdivided into areas with the same water level. More divisions as a consequence of ongoing subsidence were not taken into the model. In scenario 1 (AR) the initial costs for water-assets were not taken into account.

The sludge layer is modelled as removed once in 10 years in all scenarios, but the production of sludge differs between the scenarios, where strong drainage leads to strong growth of sludge.

Water storage (in the ditches) decreases if the soil subsides, but the levels are not adjusted. In the scenario of active rewetting this is modelled as "no storage" (this means that storage on the fields is not taken into the model). Although most scenarios will require more water (to moisten the peat), this was not taken into the model as cost or a check on availability.

In case of increasing difference in height, exceeding $60 \mathrm{~cm}$, new dikes ware modelled. The more the height of the dike, the higher the costs. Existing dikes are modelled written off in 50 years. 


\subsection{Submerged irrigation drains}

Costs for the irrigation drains were modelled as costs for the farmer as well as the profits of it. Costs for installation is modelled as EUR 2100 per hectare over 20 years life. The irrigation drains (scenario 3 ) are applied at 4500 ha of the total of 19.400 ha of peat in the AGV area. This is roughly the area where the ditch waterlevels are between 30 and $60 \mathrm{~cm}$ lower than the meadow surface level. Only the reach $30-60 \mathrm{~cm}$ is regarded as suitable for submerged irrigation drains (Troost et al., 2018). In wetter conditions the drains would "drain" too much, taking nutrient rich water to the ditch whereas in more dry peat (ditch waterlevel lower than $60 \mathrm{~cm}$ of land surface) there will be still oxygen entering below the irrigationdrain and also the tubes would have to be dug very deep. Areas with (upward) seepage are regarded as not suitable for this measure and were left out of the model.

\subsection{Water quality}

Mineralization of peat leads to $\mathrm{P}$ and $\mathrm{N}$ loads to the ditch.

We assume a $\mathrm{P}$ load of $0.00015 \mathrm{~g}$ per $\mathrm{m}^{2} \mathrm{yr}^{-1}$ surface water per $100 \mathrm{~cm}$ subsidence (Troost et al., 2018). Abrupt rewetting (scenario 1) is modelled with a big initial P-load towards the ditches.

\section{Results and Discussion}

As shown in Table 3 the subsidence will be up to $1.5 \mathrm{~m}$ by the year 2100 if we don't change policy (but in some polder units just $20 \mathrm{~cm}$ ). The strongest reduction in subsidence is calculated for scenario 1 , active rewetting. This scenario will decrease the subsidence from 1.5 to just $0.5 \mathrm{~m}$ by 2100 . Passive rewetting decreases the subsidence by half, but will only do so after 2050 , since in this approach the subsidence will not drop in the first ten years or so. Submerged drains (over 4500 ha, see Material and Methods) will have immediate effect, but the gain is $50 \mathrm{~cm}$ in 2100 compared with present policy (still $1 \mathrm{~m}$ subsidence), therefore shows the least reduction of subsidence of the 3 alternatives in 2100. The profit for the farmers (with submerged infiltration) on the other hand (Table 4), keeps in line until 2100, like the present policy, whereas in active or (a little less) in passive rewetting the profits for the farmers will be minimized by 2100 .

The costs and profits (Table 4) shows a strong negative effect on farming profit in the scenario of active rewetting (drop from 7.1 to EUR 2.5 million yearly profit) and decrease in costs of houses. In scenario 2 (passive rewetting), the costs for water authority drop (from 37.7 to EUR 29.6 million per year) (Table 4).

The results shows that the costs for water authority, greenhouse gases or public works are larger than the profit of the farmer. The houses (repair costs of foundation) show a large effect of the alternatives active and passive rewetting (cut down from 3.1 to less than EUR 1 million) but almost no ef-

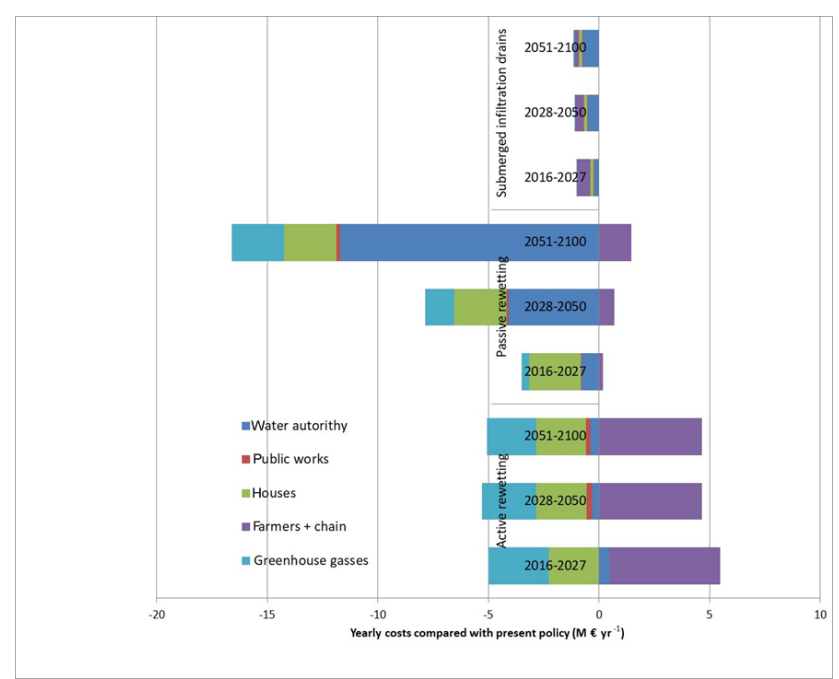

Figure 3. Average differences in yearly costs (EUR million per year) in each period in each of the 3 scenarios, compared with present policy.

fect of the alternative submerged infiltration drains. The latter can be explained by the fact that the infiltration drains will only be applied in the fields and not near the houses. But the alternatives active and passive rewetting (of the polder as a whole) will influence the foundation of the houses too. Note that (by court decision) the owners of the houses in The Netherlands will have to pay the repairs of foundation themselves.

Moreover, the costs for greenhouse gases remain high in 2100 , even if active rewetting is applied. In tons $\mathrm{CO}_{2}$-eq the emission at present (2016) is $469 \mathrm{kton}$ (or $0.469 \mathrm{Mton}$ ) for the AGV area and will drop to $393 \mathrm{kton}$ in 2100 in case of active rewetting. There is no satisfactory explanation for this result, but is well in line with the predicted subsidence in Table 3. But a likely cause is the fact that RE:PEAT uses the average groundwater levels to predict GHG emission, instead of the (perhaps more predictive with respect to GHG emissions and subsidence) mean lowest ground waterlevel.

Figure 3 shows the effects of the scenarios over the periods 2016-2027; 2027-2050 and 2050-2100 separately. This figure also zooms in on the differences in the 3 scenarios and shows a few new things:

- Scenario 3 (submerged infiltration drainage) shows little effect on costs and benefits compared to present policy.

- Passive rewetting (scenario 2) shows little effect in the first decades compared to present policy, but a strong effect towards 2100.

- Active rewetting (scenario 1) shows immediate effect compared to present policy, but no further progress as time passes. This scenario also shows that the loss in profit of the farmers is bigger than the reduction of the costs for the rest of society, in the first 10 years. 
Table 3. Soil subsidence in the 4 analyzed scenarios.

\begin{tabular}{llllll}
\hline & \multicolumn{5}{c}{ Soil Subsidence in timeframe 2016-2100 } \\
\cline { 2 - 6 } & & $\begin{array}{l}\text { Scenario 0 } \\
\text { (PP) }\end{array}$ & Scenario 1 (AR) & Scenario 2 (PR) & $\begin{array}{l}\text { Scenario 3 } \\
\text { (Submerg. Infilt.) }\end{array}$ \\
\hline $\begin{array}{l}\text { Soil Subsidence } \\
\text { (meters) }\end{array}$ & Min & 0.20 & 0.10 & 0.15 & 0.15 \\
\hline $\begin{array}{l}\text { Reason for slowing } \\
\text { down the subsidence }\end{array}$ & Max & 1.50 & 0.50 & 0.75 & 1.00 \\
\hline
\end{tabular}

Table 4. Main results in EUR million per year for the period 20162100. The table shows yearly costs, but yearly profits if the figures are negative.

\begin{tabular}{lrrrr}
\hline & $\begin{array}{r}\text { present } \\
\text { policy }\end{array}$ & $\begin{array}{r}\text { active } \\
\text { rewetting }\end{array}$ & $\begin{array}{r}\text { passive } \\
\text { rewetting }\end{array}$ & $\begin{array}{r}\text { infiltration/ } \\
\text { drains }\end{array}$ \\
\hline water autorithy & 37.773 & 37.505 & 29.592 & 37.182 \\
public works & 22.143 & 21.965 & 22.005 & 22.109 \\
houses & 3.177 & 0.911 & 0.825 & 3.037 \\
farmers + chain & -7.123 & -2.478 & -6.037 & -7.423 \\
Greenhouse gasses & 18.053 & 15.731 & 16.237 & 18.007 \\
\hline
\end{tabular}

Public works (roads, sewage, cables) show only small differences between different scenarios and appear relatively insensitive to the scenarios and time. Or one might say that public works remain a strong source of costs in peat areas.

\subsection{Sensitivity to assumptions}

The analyses showed strong sensitivity for the following parameters:

Milk price and food price in profits for the farmers. The interest, a change of $1 \%$ in interest results in a change of $15 \%$ in costs. The climate scenario: If a less strong climate scenario was used, the subsidence by 2100 would be $10 \mathrm{~cm}$ less. This especially has an effect on the costs of infrastructure (dikes, roads, pipes).

The sensitivity analysis was not carried out for method of calculation of GHG emission and the used soil map. GHG emission could also be calculated based on mean lowest groundwater level instead of mean groundwater level.

\subsection{Discussion}

The analysis was carried out to obtain a first impression and was not meant to be a very precise scientific study. It does however give some clues to fields of interest in which more elaboration is desired: a reliable groundwater model, groundwater measurements and the same holds for the emission of greenhouse gases. Also more elaboration is desired for the effects (and water consumption) of submerged infiltration drains and (the appliance of) paludiculture in case of strong rewetting.

As GHG emissions are predicted based on mean groundwater level in peat areas and submerged infiltration drains have little effect on mean groundwater levels, the effect on lowering GHG emissions will probably be underestimated.

The analysis shows that the costs for greenhouse gases plays a role, but at EUR 40 per ton cannot cover the extra costs as shown in Fig. 3, except from scenario 1 (immediate active rewetting). To cover the peat area related costs for the water authority in the period 2050-2100, would require a $\mathrm{CO}_{2}$ price of EUR 63 per ton $\mathrm{CO}_{2}$-eq. At present this would require a $\mathrm{CO}_{2}$ price of EUR 50 per ton $\mathrm{CO}_{2}$-eq.

The approach of a social costs and benefits analyses cannot show all aspects, but gives some interesting insights. Of course, there is more than money: farming is rooted in the culture and the peat meadow landscape is unique. But one could wonder if things are sustainable in the end as it is now. This study also shows that changes in land use, will not immediately stop the emissions of greenhouse gases and as well that it is not easy to take good measures against soil subsidence without making real choices in land use.

We suggest to use the model RE:PEAT in the discussions in the local areas of interest, if possible as an interactive "serious game". Local stakeholders (farmers, house owners, regional government, water authority) will have to be involved to produce tailor-made measurements against soil subsidence.

\section{Conclusions}

Based on this cost-benefit study in RE:PEAT, a change of the current water management policy is necessary to reduce societal costs due to soil subsidence. For all alternative scenarios (active rewetting, passive rewetting and submerged infiltration drains), soil subsidence will decrease compared to the standard water management policy and the societal costs will drop towards 2100 .

On short term (before 2027), active rewetting has highest impact on reducing soil subsidence and GHG emission. 
However, this would imply lower income for farmers and higher costs for water authorities on the short term. In this study, the farmer profits may be underestimated as paludiculture was not included as a business model. On short term (before 2027), submerged infiltration drains will reduce soil subsidence, while farmers will have higher income and water authorities lower costs. However, the effect of submerged infiltration drains on GHG emission is much lower than in case of active rewetting.

On long term (2100), passive rewetting will lead to the highest cost reduction for water authorities, and comparable GHG reduction and comparable cost reduction for houses as active rewetting. This would cause lower income for farmers (but not as low as in case of active rewetting).

The model is sensitive to the assumptions used, especially for farming prices. More insights are needed to improve the models in RE:PEAT, especially regarding the calculation of GHG emissions. The model should be calibrated by measurements of GHG emissions and groundwater levels.

The Paris Climate agreement (and the GHG emissions from peat) has raised the urgency to reduce the GHG emission from peat areas. Reduction of GHG emissions is a supplemental policy-goal in peat meadow areas to the subsidence itself.

Data availability. The data used for the model re:peat is inside the publication Troost et al. (2018). Furthermore data of groundwatertables were derived from within company models.

Author contributions. TP took the lead to write this paper. AMMW supported in writing the paper. ST did all of the analyses and primary reports on the work with the tool Re:Peat.

Competing interests. The authors declare that they have no conflict of interest.

Special issue statement. This article is part of the special issue "TISOLS: the Tenth International Symposium On Land Subsidence - living with subsidence". It is a result of the Tenth International Symposium on Land Subsidence, Delft, the Netherlands, 17-21 May 2021.
Acknowledgements. We would like to acknowledge Corine van den Berg for her lead in the process and Johan Ellen for his contribution in the analysis. Huub Kuipers also worked on the analysis in RE:PEAT and Niels Hoefsloot supported on the cost-benefit aspects of the study.

\section{References}

AGV: Waterbetrokken, Bestuursakkoord Waterschap Amstel, Gooi en Vecht 2019-2023, available at: (last access: 2 March 2020), 2019.

Jurasinski, G., Günther, A., Huth, V., Couwenberg, J., and Glatzel, S.: 5.1 Greenhouse gas emissions, in: Chap. 5 Ecosystem services provided by paludiculture, Paludiculture - productive use of wet 35 peatlands, Climate protection - biodiversity - regional economic benefits, edited by: Wichtmann, E., Schröder, and Joosten, H., Schweizerbart Science Publishers, Stuttgart, 7993, 2016.

Troost, S., Kuipers, H., and Hoefsloot, N.: Toekomstverkenning bodemdaling AGV, Maatschappelijke kosten en baten analyse, Aveco De Bondt, in opdracht van Waternet, Internal publication, 2018.

Waterschap Stichtse Rijnlanden: Re:peat a model for soil subsidence in peat meadow area, available at: https://www.hdsr.nl/ beleid-plannen/veenweide/onderzoeken/re-peat/ (last access: 2 March 2020), 2017.

Wosten, J. H. M., de Vries, F., Hoogland, T., Massop, H. T. L., Veldhuizen, A. A., Vroon, H. R. J., Wesseling, J. G., Heijkers, J., and Bolman, A.: BOFEK2012, de nieuwe bodemfysische schematisatie van Nederland, Wageningen, Alterra (Alterra-rapport 2387) - 46, available at: https://research.wur.nl/en/publications/ bofek2012-de-nieuwe-bodemfysische-schematisatie-van-nederland (last access: 2 March 2020), 2013.

van Beek, C. L., Droogers, P., van Hardeveld, H. A., van den Eertwegh, G. A. P. H., Velthog, G. L., and Oenema, O.: Water Air Soil Pollut, Leaching of Solutes from an Intensively Managed Peat Soil to Surface Water, 182, 291, https://doi.org/10.1007/s11270-007-9339-7, 2007.

van den Born, G. J., Kragt, F., Henkens, D., Rijken, B., van Bemmel, B., and van der Sluis, S.: Dalende bodems, stijgende kosten: mogelijke maatregelen tegen veenbodemdaling in het landelijk en stedelijk gebied: beleidsstudie, (PBL-publicatie; No. 1064), Den Haag: Planbureau voor de Leefomgeving, available at: (last access: 2 March 2020), 2016. 